\title{
Antitrust Damages and Economic Efficiency: An Approach to Antitrust Injury
}

\author{
William H. Page $\dagger$
}

Three years ago, the Supreme Court enunciated the concept of "antitrust injury,"1 which requires that antitrust-damage liability flow from the anticompetitive aspect of an unlawful practice. Since then, the concept has often been raised in litigation, and has sparked frequent judicial discussion. ${ }^{2}$ Courts and commentators, however, have developed no coherent theory to guide the application of the antitrust-injury doctrine in the award of damages for antitrust violations. This article will attempt to provide such a theory: $:^{3}$ it argues that the familiar criterion of economic efficiency gives content to the concept of antitrust injury, and therefore can be used to shape the award of antitrust damages.

\section{The Development of Antitrust InJury}

The expansion of substantive antitrust liability by the Warren Court and the simultaneous relaxation of procedural constraints on the private treble-damage action created distortions in federal antitrust policy. ${ }^{*}$ Antitrust decisions then seemed to protect competitors and distributors from "unfair" treatment in their commercial dealings rather than to improve competition and reduce prices. At the same time, partly as a result of a series of procedural decisions by the Supreme Court, ${ }^{5}$ the private plaintiff had become the

† Associate Professor of Law, Boston University. I would like to thank Professors Kenneth W. Dam and Richard A. Posner of the University of Chicago Law School, Professors Joseph F. Brodley and John Leubsdorf of Boston University School of Law, and Robert H. McGuckin of the United States Department of Justice for helpful comments on earlier drafts.

1 Brunswick Corp. v. Pueblo Bowl-O-Mat, Inc., 429 U.S. 477 (1977).

See text at note 22 infra.

s My approach here owes a good deal to the insights of Professor Areeda. See $2 \mathrm{P}$. Areeda \& D. Turner, ANTITrust Law III 333-349 (1978).

- Dam, Fortner Enterprises v. United States Steel: "Neither a Borrower, Nor a Lender Be," 1969 Sur. CT. Rev. 1, 36-40. See also Landes \& Posner, The Private Enforcement of Law, 4 J. Legal Stud. 1, 41 (1975).

- E.g., Perma Life Mufflers, Inc. v. International Parts Corp., 392 U.S. 134 (1968) (eliminating in pari delicto as a complete defense); Poller v. CBS, Inc., 368 U.S. 464 (1962) (rais- 
most important agent of enforcement. The significance of this development was clear: every nominal violation that held out the prospect of treble damages would be challenged regardless of its effects on competition. Such antitrust enforcement harmed consumers by encouraging inefficient business relationships and inhibiting aggressive competition.

Under the Burger Court, however, we have begun to witness a countervailing trend. The substantive law, although retaining many liberal rules of liability, ${ }^{6}$ now recognizes that the predominant goal of antitrust enforcement is the enhancement of competition rather than the subsidization of small and inefficient businesses. ${ }^{7}$ More importantly for our purposes here, the procedural law has also begun to recognize the same goal by imposing limits on the kinds of injuries for which private plaintiffs may recover.

The Supreme Court has recently articulated a principle that explicitiy recognizes the potential conflict between the damage remedy and the goal of the antitrust laws. In Brunswick Corp. $v$. Pueblo Bowl-O-Mat, Inc., ${ }^{8}$ following a perceptive analysis by Professor Areeda of the appellate decision in the same case, ${ }^{\circ}$ the Court interpreted the language in section 4 of the Clayton Act ${ }^{10}$ that permits recovery for "anything forbidden by the antitrust laws" to refer to the anticompetitive aspects of a violation rather than the violation itself. ${ }^{11}$ Brunswick, the nation's largest producer of equipment for bowling centers, acquired bowling centers owned by several of its defaulting customers; Brunswick continued to operate the acquired centers in competition with the plaintiffs. ${ }^{12}$ In a suit

ing standards for summary judgment); Radiant Burners, Inc. v. Peoples Gas Light \& Coke Co., 364 U.S. 656 (1961) (per curiam) (eliminating the requirement that the plaintiff prove public injury in per se cases).

${ }^{6}$ E.g., United States Steel Corp. v. Fortner Enterprises, Inc., 429 U.S. 610 (1977) (narrowly defining the economic power required to prove an illegal tying arrangement).

7 See Continental T.V., Inc. v. GTE Sylvania, Inc., 433 U.S. 36, 53 n.21 (1977).

8429 U.S. 477 (1977).

- Areeda, Antitrust Violations Without Damage Recoveries, 89 HaRv. L. REv. 1127 (1976).

1015 U.S.C. \& 15 (1976).

11429 U.S. at 488.

12 During a six-year boom in the popularity of bowling following the introduction of automatic pinsetters in 1956, Brunswick's sales to bowling centers increased dramatically; most of the sales were financed by Brunswick itself. Id. at 479; Brief for Petitioner at 6 . In 1962, however, sales of new equipment fell by one-half and continued to decline until the early 1970s. Id. at 7 n.5. Many of Brunswick's customers defaulted. The company began repossessing the equipment, and, when it was unable to resell it, managing the centers through its Bowling Center Operations Division. 429 U.S. at 478-80. By the time the suit was originally filed in 1966, Brunswick was the largest national chain of bowling centers 
alleging violations of section 7 of the Clayton Act, ${ }^{13}$ the plaintiffs claimed as damages the profits they would have gained had Brunswick not continued to operate the defaulting centers. ${ }^{14}$ The court of appeals ruled that if the acquisition were found to be illegal under a proper instruction, ${ }^{15}$ any injury causally related to the presence of Brunswick in the market would be recoverable as damages, whether or not the injury resulted from a lessening of competition. ${ }^{16}$

The Supreme Court, in a unanimous opinion by Justice Marshall, vacated the appellate court's decision, and ordered entry of judgment for Brunswick notwithstanding the verdict on the damage issue. ${ }^{17}$ Justice Marshall distinguished the substantive prohibition, which requires only an incipient or potential effect on competition, and the damage provision, which requires proof of actual injury. "Plainly," he wrote, "to recover damages respondents must prove more than that petitioner violated $\S 7$, since such proof es-

with over five times as many centers as its next largest competitor. Id. at 480 .

1315 U.S.C. $\S 18$ (1976).

14 After one mistrial, the case finally went to the jury in 1973. The jury was instructed that "any percentage of the market achieved by Brunswick . . . beyond an insubstantial amount, say beyond 10 to $15 \%$, may be sufficient for you to conclude that competition has substantially been lessened." Record at 4727, reprinted in Petition for Certiorari (Appendix A), at A1499-500. As to the amount, it was instructed to include "all damages suffered by the plaintiffs because of lost profits; that is to say, profits that the plaintiff would have made if Brunswick has not violated the antitrust laws." Id. at 4733 , reprinted in Petition for Certiorari (Appendix A), at A1503. The court further charged that damages for the violation should be within the range offered by plaintiff's experts. Id. at 4736-42, reprinted in Petition for Certiorari (Appendix A), at A1505-09. The jury returned a verdict equal to the lowest estimate of the plaintiff's experts, and after a remittitur as to damages for one of the bowling centers, the court entered judgment. Treadway Cos. v. Brunswick, 364 F. Supp. 316 (D.N.J. 1973). In a later ruling, the court, sitting in equity, ordered Brunswick to divest itself of the illegally acquired centers. Treadway Cos. v. Brunswick Corp., 389 F. Supp. 996 (D.N.J. 1974).

15 The court of appeals reversed on the ground that the charge to the jury on the liability issue was "virtually a directed verdict," because it emphasized market shares to the exclusion of the specific capability of Brunswick to monopolize the affected markets. NBO Indus. Treadway Cos. v. Brunswick Corp., 523 F.2d 262, 274 (3d Cir. 1976). It refused to order a directed verdict for Brunswick, since, it said, there was evidence sufficient to go to the jury that Brunswick's "deep pocket" preserved centers that would otherwise have failed, and gave Brunswick the power to finance anticompetitive practices. Id. at 273 . It also reversed the divestiture order, saying that "Iess drastic relief will provide sufficient redress." Id. at 279.

16 Id. at 273.

17 Brunswick Corp. v. Pueblo Bowl-O-Mat, Inc., 429 U.S. 477, 490-91 (1977). The decision on injunctive relief was not disturbed because Brunswick had not petitioned for certiorari on the issue. 
tablishes only that injury may result."18 Justice Marshall then rejected the ruling by the court of appeals that all injury caused by a violation is compensable; he noted that such a ruling "divorces antitrust recovery from the purposes of the antitrust laws."19 Congress did not prohibit mergers because they cause economic readjustments, but because they may reduce competition.

Justice Marshall reasoned that since liability was based on Brunswick's capacity to finance predatory practices out of its "deep pocket," any recoverable damages must be traceable to predatory conduct. But since the measure of damages that the court of appeals adopted was based solely on the profits lost by the plaintiffs after Brunswick began operating the defaulting centers-profits lost, in other words, because of continued competition-it was inconsistent with the basis of substantive liability. More importantly, that measure of damages was also inconsistent with the fundamental purpose of the antitrust laws: "The damages respondents obtained are designed to provide them with the profits they would have realized had competition been reduced."20 To permit such a damage award would be to confuse injury to competitors with injury to competition. The Court therefore held that

for plaintiffs to recover treble damages on account of $\S 7$ violations, they must prove more than injury causally linked to an illegal presence in the market. Plaintiffs must prove antitrust injury, which is to say injury of the type the antitrust laws were intended to prevent and that flows from that which makes defendants' acts unlawful. The injury should reflect the anticompetitive effect either of the violation or of anticompetitive acts made possible by the violation. It should, in short, be "the type of loss that the claimed violation ... would be likely to cause."21

Since Brunswick was decided, the defense bar has seized upon the notion of "antitrust injury" as a weapon of commercial warfare, raising it routinely as a defense in treble-damage litigation. The antitrust-injury concept has become one of profound practical and theoretical importance, although the courts have not been uni-

18 Id. at 486.

10 Id. at $486-87$.

${ }^{30} I d$. at 488.

${ }^{21}$ Id. at 489 (emphasis in original) (quoting Zenith Radio Corp. v. Hazeltine Research, Inc., 395 U.S. 100, 125 (1969)). 
formly receptive to it. ${ }^{22}$ But the decisions indicate that the courts and litigants lack any firm conceptual basis for identifying antitrust injury.

Such a basis is provided, however, by the recognition that antitrust policy should be directed toward promoting efficiency, or as some prefer to call it, consumer welfare. ${ }^{23}$ The "rule of reason"24 narrows the class of illegal restraints from all those that limit any individual's commercial freedom to those that limit the efficient operation of markets generally. In parallel fashion, antitrust injury can consistently be seen as narrowing the standard for recoverable damages from all those suffered by the plaintiff as a result of an antitrust violation to those that actually flow from the aspect of the violation that causes market inefficiency. As the Supreme Court has said, the Sherman Act was

enacted to prevent not the mere injury to an individual which would arise from the doing of the prohibited acts, but the harm to the general public which would be occasioned by the evils which it was contemplated would be prevented, and hence not only the prohibitions of the statute but the remedies which it provided were coextensive with such conceptions. ${ }^{25}$

22 Many courts have refused to extend the concept of antitrust injury as a limitation on damages. See, e.g., Lee-Moore Oil Co. v. Union Oil Co., 599 F.2d 1299, 1302-03 (4th Cir. 1979); Purex Corp. v. Procter \& Gamble Co., 596 F.2d 881, 888 (9th Cir. 1979); Ohio-Sealy Mattress Mfg. Co. v. Sealy, Inc., 585 F.2d 821, 832-33 (7th Cir. 1978), cert. denied, 440 U.S. 930 (1979); Heatransfer Corp. v. Volkswagenwerk, A.G., 553 F.2d 964, 984-85 (5th Cir. 1977), cert. denied, 434 U.S. 1087 (1978); Fuchs Sugars \& Syrups, Inc. v. Amstar Corp., 447 F. Supp. 867, 878 (S.D.N.Y. 1978); Laughlin v. Wells, 446 F. Supp. 48, 52 (C.D. Cal. 1978); L \& H Investments, Ltd. v. Belvey Corp., 444 F. Supp. 1321, 1323-25 (W.D.N.C. 1978); Admiral Theatre Corp. v. Douglas Theatre Co., 437 F. Supp. 1268, 1295-96 (D. Neb. 1977), aff'd, 585 F.2d 877 (1978). Defendants have had some success under the new doctrine, however. See, e.g., Lupia v. Stella D'Oro Biscuit Co., 586 F.2d 1163, 1168-69 (7th Cir. 1978), cert. denied, 440 U.S. 982 (1979); John Lenore \& Co. v. Olympia Brewing Co., 550 F.2d 495, 498-500 (9th Cir. 1977), cert. denied, 440 U.S. 990 (1979); Outboard Marine Corp. v. Pezetel, 461 F. Supp. 384, $401-03$ (D. Del. 1978); Uniroyal, Inc. v. Jetco Auto Serv., Inc., 461 F. Supp. 350, 359 (S.D.N.Y. 1978); Murphy Tugboat Co. v. Crowley, 454 F. Supp. 847, 852-57 (N.D. Cal. 1978); Juneau Square Corp. v. First Wis. Nat'l Bank, 445 F. Supp. 965, 973-76 (E.D. Wis. 1978).

2s See R. Bork, The Antitrust Paradox 50-133 (1978); W. Bowman, Patent and ANtitrust Law 1-14 (1973); R. Posner, Antitrust Law: An Economic Perspective 18-22 (1976) [hereinafter cited as Economic Perspective]; Dam, supra note 4, at 28-31, 39-40; Director \& Levi, Law and the Future: Trade Regulation, 51 Nw. U.L. Rev. 281 (1956); Schwartz, Book Review, 43 U. ChI. L. Rev. 858 (1976). But see L. Sullivan, Handbook of THE LAW OF ANTITRUST 2-13 (1977).

24 See Standard Oil Co. v. United States, 221 U.S. 1, 60, 63-68 (1911).

${ }^{25}$ D.R. Wilder Mfg. Co. v. Corn Prods. Ref. Co., 236 U.S. 165, 174 (1915) (emphasis added). 
The interpretation of the language of both the substantive and the remedial provisions of the antitrust laws must therefore be guided by the overall statutory purpose of promoting competition. And just as economic analysis of the effects of various practices on efficiency should guide the development of the rule of reason in the formulation of substantive rules, so the same tools should give content to the concept of antitrust injury.

\section{The Deterrent Function of Treble Damages}

If treble-damage actions are to promote economic efficiency, the size of the award should approximate the social cost or inefficiency caused by the violation, discounted by the likelihood that the conduct will be discovered and penalized. ${ }^{26}$ Firms will not engage in a practice if their expected gain in doing so is less than their expected (private) cost, including any penalties incurred for violating the antitrust laws. If this expected cost exceeds the social cost, firms will be deterred from pursuing activities that promise greater value than any inefficiency resulting from those activities. This danger is particularly great where the activity enables the firm to achieve economies by the integration of productive or distributive processes, yet causes no immediate reductions in output. But even if the activity has no such redeeming qualities, an excessive penalty may deter similar, efficient activities that firms only perceive as violations because the law is unclear. ${ }^{27}$ In either case, deterrence of the conduct by penalties unrelated to the social cost would itself be inefficient.

The bulk of this article will consider the difficulties inherent in using private damage awards as a deterrent to anticompetitive conduct. Any analysis along the lines I am suggesting necessarily assumes that the primary function of the treble-damage action is deterrence of such conduct rather than compensation of victims, subsidization of small businesses, or similar goals directed to the private rather than the social cost of violations. This assumption is justified, however, on the basis of both statutory interpretation

${ }^{26}$ See Economic Perspective, supra note 23, at 221-24; Becker, Crime and Punishment: An Economic Approach, 76 J. Pol. EcoN. 169, 176-79, 180-85, 191-93 (1968).

${ }^{27}$ See United States v. United States Gypsum Co., 438 U.S. 422 (1978); R. Bork, supra note 23 , at 78 ("Just as protected speech lies next to that which may be outlawed, so does vigorous price competition adjoin that which goes too far and is predatory. It is not socially desirable that conduct in either of the two adjacent areas be deterred."); R. POSNER, EcoNOMIC ANALYsis of Law $\S 20.4$ (2d ed. 1977). 
and sound policy considerations.

The legislative history of the Sherman Act is notoriously malleable, assuming virtually any shape the advocate desires. Nonetheless, there is evidence in the early congressional debates to support the primacy of the deterrent function. The present section 4 of the Clayton Act follows the language of the original section 7 of the Sherman Act, ${ }^{28}$ which Thorelli concludes, in his authoritative study ${ }^{29}$ of the debates, was intended to make the antitrust law selfenforcing, in keeping with the vision of an efficiently operating economic system. By creating incentives for those injured by monopolistic practices to seek redress in the courts, section 7 was designed to encourage individuals to enforce the Sherman Act for the benefit of society. ${ }^{30}$ At the same time, the framers of the section seem to have had no illusions about its suitability as a vehicle for compensating those injured by monopolistic practices. The number of individuals injured would normally be so large that the courts would be incapable of providing full and fair compensation. The framers explicitly rejected, for example, an amendment that would have permitted joinder as plaintiffs of all those injured by a violation. $^{31}$ One can conclude that they expected the statute to deter anticompetitive conduct rather than systematically to make whole those who had been injured by past inefficiency. A similar purpose may be gleaned from the legislative history of the Clayton Act. ${ }^{32}$

The Supreme Court's interpretation of section 4 of the Clayton Act has generally reinforced the provision's role as a deterrent. $^{33}$ The Hanover Shoe ${ }^{34}$ and Illinois Brick ${ }^{35}$ decisions, for example, held that direct purchasers are, as a matter of law, the persons injured by illegal overcharges, even if part of the cost increase was passed on to others. Recognizing the complexity of the

28 Sherman Act, ch. 647, § 7, 26 Stat. 209 (1890) (superseded by Clayton Act, § 4, 15 U.S.C. $§ 15$ (1976)).

$29 \mathrm{H}$. Thorelli, The Federal Antitrust Policy (1955).

so Id. at $225,229,588$.

3121 Cong. Rec. 3147-48, 3150-51 (1890). See also 21 Cong. Rec. 1767-68 (1890) (remarks of Sen. George).

${ }^{32}$ See 51 Cong. REc. 16274-75 (1914) (remarks of Rep. Webb) (treble damages "will have a more deterrent effect on the men who practice those things than a mere criminal penalty").

ss See, e.g., Pfizer, Inc. v. Government of India, 434 U.S. 308, 315 (1978); Nashville Milk Co. v. Carnation Co., 355 U.S. 373, 387 (1958) (Douglas, J., dissenting); Bruce's Juices, Inc. v. American Can Co., 330 U.S. 743, 751-52 (1947).

s4 Hanover Shoe, Inc. v. United Shoe Mach. Corp., 392 U.S. 481, $487-94$ (1968).

ss Illinois Brick Co. v. Illinois, 431 U.S. 720 (1977). 
evidentiary issues that would have to be resolved if the theory of passing on were permitted for either plaintiffs or defendants, the Court found that

the legislative purpose in creating a group of " private attorneys general" " to enforce the antitrust laws under $\S 4 \ldots$ is better served by holding direct purchasers to be injured to the full extent of the overcharge paid by them than by attempting to apportion the overcharge among all that may have absorbed a part of it. ${ }^{36}$

The Court recognized that it is more important that the penalty be imposed than that the damages be divided fairly. On the other hand, in Reiter $v$. Sonotone Corp., ${ }^{37}$ the Court found that ultimate consumers should be permitted to recover if they are direct purchasers, since to deny them standing would allow the price fixing to go unchallenged altogether.

Brunswick, however, contains a passage that, at first sight, is troubling:

[T]reble damages also play an important role in penalizing wrongdoers and deterring wrongdoing, as we also have frequently observed. . . . It nevertheless is true that the trebledamages provision, which makes awards available only to injured parties, and measures the awards by a multiple of the injury actually proved, is designed primarily as a remedy. ${ }^{38}$

Although easily misunderstood, this passage is fully consistent with the deterrence rationale if read in context. By characterizing the purpose of section 4 as remedial, the Court emphasized that damages must be for actual injury; it did not suggest that damages should compensate all those injured by antitrust violations. The remainder of the opinion makes clear that implicit in the Court's understanding of the remedial function is the requirement that any damage recovery be related to the inefficiency-causing effects of the conduct in question. ${ }^{39}$

The Court's reasoning and the legislative history giving priority to the deterrent function are consistent with an economic interpretation of the function of antitrust damages. Although damages

\footnotetext{
${ }^{\text {se }}$ Id. at 746 (quoting Hawaii v. Standard Oil Co., 405 U.S. 251, 262 (1972)).

37442 U.S. 330 (1979).

38 429 U.S. at $485-86$ (citations and footnote omitted).

39 Id. at 486-89.
} 
certainly serve to compensate as well as to deter, ${ }^{40}$ the principal function of compensation from an economic point of view should be to spur private parties to bring suit; to the extent the deterrent function is served, compensation will become unnecessary, because the amount of competitive harm will be reduced. ${ }^{41}$ Since litigation is costly, deterring future violations would waste fewer real resources than would be wasted by simply providing compensation whenever violations occur. Furthermore, antitrust actions are unlikely to accomplish compensation in any equitable way. As Professor Posner has noted,

Everybody's economic welfare is bound up with everybody else's. Why stop with the ultimate consumer? If he is forced to pay a higher price for a product, his demand for other products will fall and this may hurt the suppliers of those products, and the suppliers' suppliers, and so on ad infinitum. ${ }^{42}$

As the antitrust-standing cases recognize, ${ }^{43}$ it is impossible for the damage provison to restore all the individual members of society to the position they would have held but for the violation.44

Even theoretically, compensation cannot be separated from deterrence as an objective of antitrust remedies. Treble-damage awards will deter the conduct penalized regardless of the rationale for imposing the award. If the size of the penalty is unrelated to the anticompetitive effects of the conduct involved, the damage award will either leave incentives to engage in anticompetitive conduct or create deterrents to efficient conduct. The central insight of Brunswick was that there are inefficient levels of deterrence. ${ }^{45}$

so See, e.g., Areeda, supra note 9.

41 See Landes \& Posner, Should Indirect Purchasers Have Standing to Sue Under the Antitrust Laws? An Economic Analysis of the Rule of Illinois Brick, 46 U. CHI. L. REv. 602, 605 (1979).

12 R. Posner, Antitrust: Cases, Economic Notes, \& Other Materials 149 (1974).

is See text and notes at notes 116-136 infra.

"The lower courts have been virtually unanimous in concluding that Congress did not intend the antitrust laws to provide a remedy in damages for all injuries that might conceivably be traced to an antitrust violation." Hawaii v. Standard Oil Co., 405 U.S. 251, 262 n.14 (1972).

15 The Court has recognized the danger of overdeterrence in other contexts. See, e.g., id. at 262-64 (state denied right to sue for damages to its "general economy" because a recovery would duplicate damages of other potential plaintiffs); Illinois Brick Co. v. Illinois, 431 U.S. 730, 730-31 (1977) (permitting indirect purchasers to sue, while presuming that the direct purchaser has not passed on the illegal overcharge, "substantially increases the possibility of inconsistent adjudications-and therefore of unwarranted multiple liability for the 
Since the antitrust laws "were enacted for "the protection of competition, not competitors," gains associated with a nominal violation would contradict the underlying purpose of the law.

\section{Toward a Definition of Antitrust InJuRy}

As noted earlier, in order to deter anticompetitive activity, the amount of damages awarded should equal the efficiency loss to society attributable to the defendant's conduct, discounted by the likelihood of the violation being discovered. But private treble damages only roughly approximate this standard. The trebling of damages, for example, was never intended to be a discounting factor, ${ }^{47}$ and scarcely serves that function. It seems to overstate the likelihood of apprehension for concealable offenses such as price fixing, ${ }^{48}$ and to understate it for other easily detectable offenses, such as tying arrangements. Furthermore, a number of practical limitations prevent the final damage award from ever truly reflecting the actual injury to either the plaintiff or society. The available accounting data, for example, may be insufficient to justify any award, and when an award is made, its relationship to the actual injury may be tenuous at best. ${ }^{49}$ Other factors, such as the tax treatment of damage awards and the statute of limitations, may limit the deterrent force of a damage award. ${ }^{\circ 0}$ But all of these constraints are common to any system of liability, and do not represent conclusive grounds for doubting the suitability of the statutory scheme for its purpose.

There is, however, a more serious potential flaw in a statutory scheme that relies on the private damage action to achieve the economically appropriate level of deterrence: the efficiency loss to society that should determine the level of deterrence does not coincide with the losses that individual economic actors suffer from

defendant"). See also Kelly v. Kosuga, 358 U.S. 516 (1959).

${ }^{48}$ Brunswick Corp. v. Pueblo Bowl-O-Mat, Inc., 429 U.S. 477, 488 (quoting Brown Shoe Co. v. United States, 370 U.S. 294, 320 (1962)).

17 The trebling provision was imported from the original Statute of Monopolies, 21 Jac. 1 , c. 3 (1624).

48 Criminal penalties for these offenses partly compensate for the inadequacy of the discounting factor. See 15 U.S.C. $\S \S 1,2$ (1976).

${ }^{4}$ See Note, Private Treble Damage Antitrust Suits: Measure of Damages for Destruction of All or Part of a Business, 80 HaRv. L. REv. 1566, 1572-74 (1967).

so See, e.g., Parker, Treble Damage Action-A Financial Deterrent to Antitrust Violations?, 16 Antitrust Bull. 483 (1971); Wheeler, Antitrust Treble-Damage Actions: Do They Work?, 61 CaLIF. L. REv. 1319 (1973). 
antitrust violations. In Brunswick, for example, the unlawful acquisitions caused no inefficiency, but had a substantial impact on the profitability of the competing bowling centers. This disjunction between the private and social cost of antitrust violations is not unique to the facts of Brunswick. ${ }^{51}$ Many violations are forms of aggressive competition that have crossed the indistinct line into the region the law deems predatory. Analogously, other violations involve integrations of productive or distributive processes that result in real economies. Although there may be no social cost-or harm to consumers-from these nominal violations, the harm to competitors or distributors may be quite concrete. This flaw is more serious than the use of an incorrect multiple to discount for the probability of apprehension, because individual injury may bear no relation at all to the social cost of the violation.

The concept of antitrust injury goes a long way toward correcting this imbalance. The Brunswick Court defined antitrust injury as "injury of the type the antitrust laws were intended to prevent and that flows from that which makes the defendants' acts unlawful." tors that is traceable to those aspects of the violation that cause economic inefficiencies. Approaching the efficient level of deterrence requires an analysis of the competitive effects of violations and the kinds of individual injury associated with them. Although the individual's injury, even under this approach, is not identical to the total inefficiency associated with the violation, it is nonetheless related to it, and the relationship keeps the potential damage award connected with its deterrent purpose.

In this section I will try to show, using a discussion of the efficiency effects of various practices as a paradigm, that the concept of antitrust injury is implicit in some principal rules of antitrust damages. A description of the economics of antitrust injury as the courts have viewed it in cartel cases and in certain cases involving exclusionary practices will provide a framework for testing the implications of the concept in other settings.

51 The language of the Clayton Act requires only that the effect on competition be incipient in order to establish a violation. 15 U.S.C. $\S 18$ (1976). In such cases, no direct effect on market price need be shown. But the idea of incipiency is not confined to this statute: the Sherman Act also has consistently been read in this way. See Klor's, Inc. v. BroadwayHale Stores, Inc., 359 U.S. 207, 213-14 (1959). See also Chrysler Credit Corp. v. J. Truett Payne, Inc., 607 F.2d 1133, 1136-37 (5th Cir. 1979) (Robinson-Patman Act).

$\checkmark 2429$ U.S. at 489 (1977). 


\section{A. Cartels}

Cartels and horizontal mergers reduce allocative efficiencyreallocating resources in a way that reduces the value of society's output to consumers-if they provide the participants with the power to raise the market price above the competitive level. ${ }^{.3}$ At the higher price, the industry's output is necessarily lower, resulting in an inefficient use of resources; the output that consumers would value above the cost of production is lost. This reduction in value is what economists call the deadweight or "triangle" loss in welfare attributable to monopoly. The higher price also provides the sellers with monopoly profits, but this effect has not traditionally been viewed as either efficient or inefficient in itself. The mo-

ss The relative efficiency of competitive and cartelized markets can be illustrated diagrammatically. See Economic Perspective, supra note 23, at 10. See also C. K. Rowrey, ANTitrust AND ECONOMIC Erficiency 18-19 (1973); Harberger, Monopoly and Resource Allocation, 44 Am. Econ. Rev. Papers \& Proc. 77 (1954).

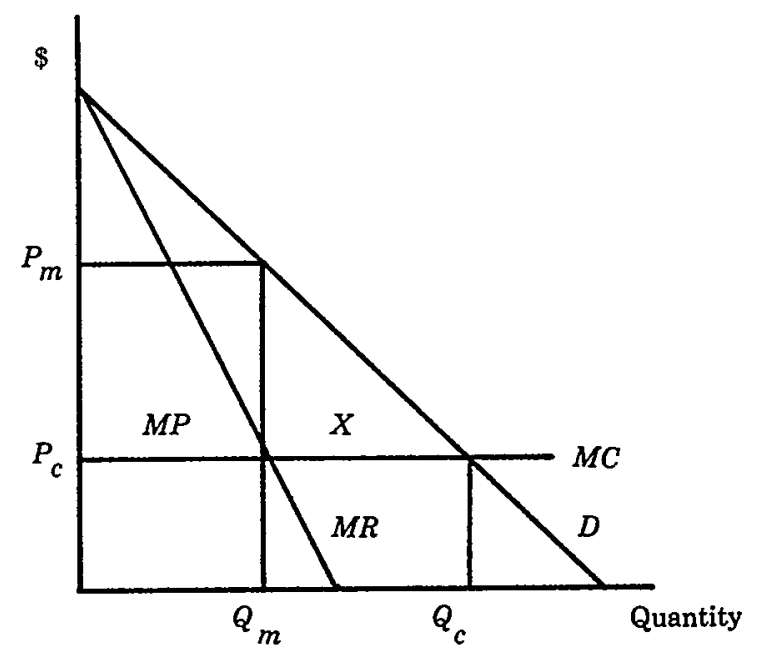

The industry demand curve $D$ represents the amount of the product consumers are willing to buy at each price. At the competitive output $\left(Q_{c}\right)$, the price $\left(P_{c}\right)$ is equal to the cost $(M C)$ of producing the last unit of output. The area under the demand curve but above $M C$ represents the surplus value to consumers of the product at $P_{c}$, who would have purchased the product at higher prices. By collusively restricting output to $Q_{m}$, where marginal revenue $(M R)$ is set equal to $M C$, the producers obtain the monopoly profit represented by the area $M P$ by capturing part of the consumers' surplus that existed under competition. The triangular area $X$ represents the so-called deadweight welfare loss created by the restriction of output: it is value lost to consumers (who are forced to seek out more costly substitutes) and not recaptured by the producers. 
nopoly profits represent only a transfer of income from one group, the purchasers of the monopolized product, to another, the owners of the firm selling the product. ${ }^{\text {s }}$

Thus, the usual economic objection to price fixing is not that it redistributes income by generating monopoly profits, but that it creates a deadweight welfare loss to society by restricting output. Yet the courts have uniformly held that the proper measure of damages in price-fixing cases is the overcharge, the difference between cartel price and the competitive price, variously defined.5s The private injury-which would in the limit equal the monopoly profits-is distinct from the social cost. ${ }^{.8}$

It is nonetheless clear that the traditional measure of damages is economically sound. Although the monopoly profits are a transfer payment, they flow from the aspect of the conduct that causes inefficiency, since they are created by the same output restriction that creates the deadweight loss. We need not accept the hypothesis that these profits also approximate a social cost of the cartel to see that they are properly regarded as illicit.. ${ }^{57}$ They are caused by the output restriction-a market inefficiency-and represent an inducement to create it, ${ }^{68}$ without increasing social wealth.

The full overcharge is a proper measure of damages even if part of it is paid to the defendant's nonconspiring competitors who sell at the cartel price. ${ }^{5 \theta} \mathrm{A}$ collusive price increase may call forth greater output from less efficient but competitive firms that take

54 Professor Posner has argued that the area $M P$, in the diagram in note 53 supra, should also be viewed as a welfare loss since it approximates the amount of real resources wasted in seeking and maintaining a monopoly position. Posner, The Social Costs of Monopoly and Regulation, 83 J. PoL. EcoN. 807 (1975).

ss E.g., Hawaii v. Standard Oil Co., 405 U.S. 251, 262 n.14 (1972); Chattanooga Foundry \& Pipe Works v. Atlanta, 203 U.S. 390 (1906).

so See Breit, Efficiency and Equity Considerations, 8 Sw. U.L. Rev. 539, 542-43 (1976).

${ }^{57} \mathrm{By}$ the same theory, illegal wealth-maximizing conduct by a monopolist may result in compensable transfer payments even if the conduct does not in itself cause an output restriction. Hanover Shoe Co. v. United Shoe Mach. Corp., 392 U.S. 481 (1968). But see SCM Corp. v. Xerox Corp., 463 F. Supp. 983 (D. Conn. 1978) (damages to potential competitors caused by defendant's refusal to license patents not recoverable).

so There are social benefits if monopoly profits are reinvested in product improvement, cost-reduction programs, and innovation. But such a defense should be inadmissible since it is equally likely that the cost reductions and innovation would have occurred under competition. C. Bane, The Electrical Equipment Conspiracies: The Treble Damages Actions 67 (1973). See also Ohio Valley Elec. Corp. v. General Elec. Co., 244 F. Supp. 914, 941-42 (S.D.N.Y. 1965).

so Wall Prods. Co. v. National Gypsum Co., 357 F. Supp. 832, 840-42 (N.D. Cal. 1973). But see Mid-West Paper Prods. Co. v. Continental Group, Inc., 596 F.2d 578, 586 (3d Cir. 1979). 
the cartel price as given. ${ }^{60}$ These firms have no incentive to set a lower price, since they can sell all they produce at the cartel price. Although their output reduces the cartelists' power to increase the price above the competitive level, whatever collusive price increase that does occur must flow directly from the cartelists' restriction of output. It is true that in these circumstances the price increase does not result in a simple wealth transfer to the cartel; part of the overcharge will go to the nonconspiring firms. Nonetheless, the inefficiency-both from the cartelists' own output restriction and from the increased output of less efficient firms-is directly attributable to the cartel. ${ }^{61}$

60

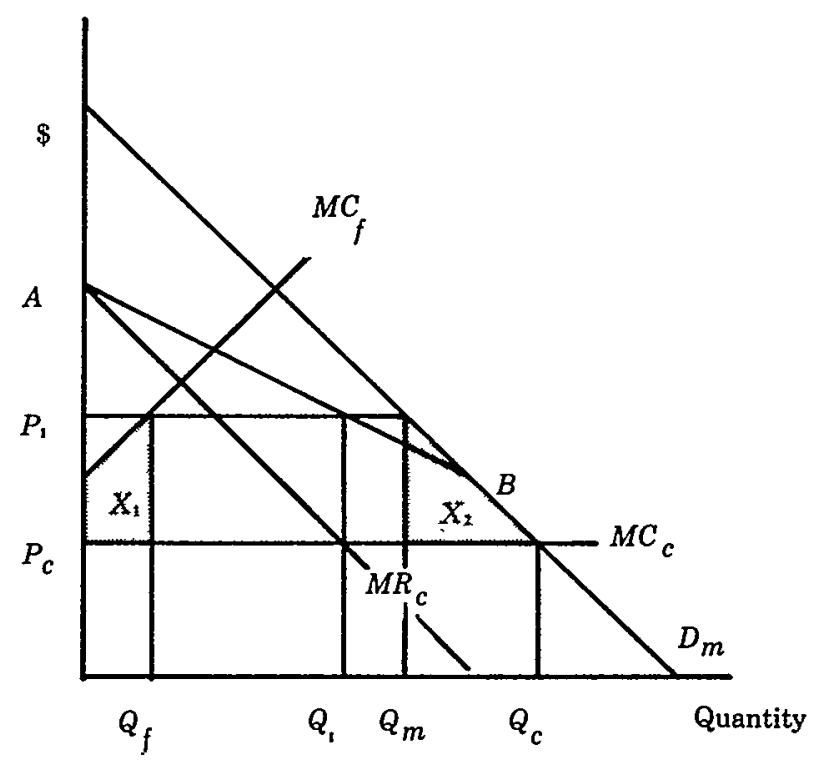

At the competitive price $P_{c}$, the market supply curve $M C_{c}$ intersects the market demand curve $D_{m}$ at output $Q_{c}$. If firms agree to restrict output, they must take account of the output of nonconspiring firms (whose supply curve is given by $M C_{f}$ ) that will enter the market at the higher prices. By subtracting these firms' output from the market demand at any given price, the cartel can constrúct the demand curve that it faces $(A B)$ and the marginal revenue curve $\left(M R_{c}\right)$ drawn to $A B$. It may then set its profit-maximizing output where $M C_{c}$ intersects $M R_{c}$, yielding a price of $P_{2}$. At that price, the nonconspirators will expand output to $Q_{f}$, where $M C_{f}$ equals $P_{1}$. The total market output then is $Q_{f}+Q_{1}^{\prime \prime}$ or $Q m$. The area $X_{1}$ represents the cost increase from the increased production of the less efficient nonconspirators; the area $X_{2}$ represents the welfare loss from the restriction of market output from $Q_{c}$ to $Q_{m}$.

61 The larger deterrent penalty is justified here since much of the overcharge paid to the nonconspiring firms reflects increased production costs (the area $X_{1}$ in the diagram in 
Those who pay illegal overcharges are not the only ones who suffer antitrust injury as a result of a cartel: the restriction of production may cut off entirely some who would have purchased the affected goods at the competitive price. The cartel members may, for example, refuse to deal at all with a distributor, or may raise their price beyond the distributor's ability to pay. ${ }^{62}$ Under such circumstances the distributor would be forced to seek out alternative but less preferable sources of supplies, suffering antitrust injury in the form of increased transaction costs and higher prices. These increased costs, even more than the overcharge itself, flow from the inefficiency-causing aspect of the cartel because the distributor has been forced to purchase more costly substitutes for the affected product.

Damages based upon this theory, of course, will often be too speculative to support recovery. ${ }^{63}$ Since anyone can assert that he

note 60 supra).

${ }^{62}$ On refusal to deal, see, for example, Engine Specialities, Inc. v. Bombardier Ltd., 605 F.2d 1, 12-15 (1st Cir. 1979); Lee-Moore Oil Co. v. Union Oil Co., 599 F.2d 1299 (4th Cir. 1979).

On raising price, see, for example, the early case of Gibbs v. McNeeley, 102 F. 594 (D. Wash. 1900), rev'd, 118 F. 120 (9th Cir. 1902), where suppliers of cedar shingles had formed "an unincorporated association having for its purpose the prevention of injurious competition," id. at 595, an object that they accomplished by a restriction of production that included a 60-day closing of the members' mills. The plaintiff, a distributor of cedar shingles, alleged that the price increase that accompanied the output restriction had caused his customers to refuse to purchase from him and that the closing of the mills had caused him to lose sales he would otherwise have made. The trial court's dismissal of the claims on the grounds that the suppliers' association did not affect interstate commerce was later reversed, but no decision on the merits was ever reported. There would seem to be no theoretical reason why these damages should not be compensable. The defendants' conduct is, in effect, a refusal to deal except upon an unlawful condition, the payment of the cartel price. See Eastman Kodak Co. v. Southern Photo Materials Co., 273 U.S. 359, $376-78$ (1927); R. PosNER, supra note 42 , at 539. The plaintiff's damages flow from the collusive price increase: if the price increase raised the plaintiff's cost and hence his prices, to the extent that his purchasers substituted toward more costly roofing materials, and if it could be shown that the plaintiff would have purchased and resold the shingles at the competitive price, then the plaintiff should recover his damages. Because of the rule requiring mitigation of damages, see text and notes at notes 77-82 infra, recovery would be limited by the difference between the collusive price and the cost of substitutes.

Identical reasoning would apply to the mill closings; the inability of the plaintiff to obtain the product because of the closings is indistinguishable from his being charged a collusive price that exceeds what his purchasers are willing to pay. An appropriate measure of damages under such circumstances would be the plaintiff's fixed costs and his anticipated accounting profit. This measure would reimburse him in an amount approximating his cost of being in the business of reselling the cartelists' product.

os See generally Wolfe v. National Lead Co., 225 F.2d 427, 432 (9th Cir.), cert. denied, 350 U.S. 915 (1955); Amexican Sea Green Slate Co. v. O'Halloran, 229 F. 77, 80-81 (2d Cir. 1915). 
would have purchased the product at the competitive price, the plaintiff must prove by a prior course of dealings or by actual offers to purchase during the conspiracy period that he would have done so. These conditions will be satisfied in some circumstances. Consider, for example, a middleman who contracted to supply uranium for a period of years at a certain price. If he is forced to break the contract because his own suppliers collusively raise the price, he should recover from his suppliers whatever damages he must pay for breach of contract.

The foregoing measures of damages do not deter any gains in productive efficiency ${ }^{64}$ - that is, reductions in the average cost of production-that a horizontal agreement makes possible. Such arrangements, particularly mergers, may increase efficiency in production if they reduce the firm's unit costs by an integration of productive, managerial, or financial facilities. ${ }^{65}$ Although these

B4 Productive efficiency consists of minimizing the costs of the individual firm for any given level of output. See generally E. RoBinson, The StRucture of Competitive INDUSTRY (4th ed. 1958). Cartels do not necessarily reduce the average costs of production; participation in a cartel may raise the firm's costs by requiring expenditures for policing or various forms of nonprice competition. Posner, supra note 54. Further, some have argued that reduction in competition because of participation in a cartel may reduce the firm's incentive to minimize costs, resulting in "X-inefficiency." See, e.g., C.K. RowLEY, supra note 53, at 53; Leibenstein, Allocative Efficiency vs. "X-Efficiency," 56 AM. Econ. REv. 392 (1966). But see Stigler, The Xistence of X-Efficiency, 66 AM. Econ. REv. 213 (1976).

${ }^{65}$ Professor Williamson illustrates this development with the following "naive tradeoff model":

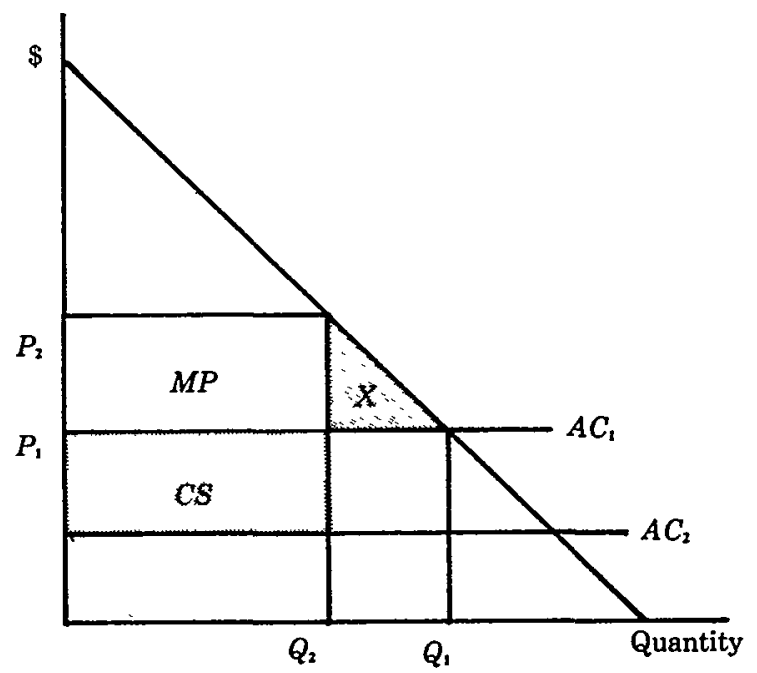

The welfare loss $(X)$ from the restriction of output is still present, but it is compensated by an increase in efficiency (CS) represented by a reduction in cost from $A C_{1}$ to $A C_{2}$. The cost savings result in higher economic profit for the producer, but release real resources for other productive uses. Williamson, Economies as an Antitrust Defense: The Welfare Trade-Offs, 58 Am. Econ. Rev. 18, 21 (1968). See also R. Bork, supra note 23, at 107. 
kinds of economies do not justify a cartel ${ }^{68}$ or a merger that reduces output, ${ }^{67}$ they should not be actively deterred by the damage remedy since they represent a social benefit that may partially offset any allocative inefficiency. These cost savings represent part of the profit generated by the cartel, and are in that respect an inducement to engage in the cartel activity. But to set damages equal to the cost savings would represent overdeterrence.

Of course, a purchaser who paid an overcharge would not recover the savings in any case, since the portion of the price attributable to the cost savings would have been paid in the absence of the cartel. Individuals directly injured by the cost savings also are not entitled to recover any damages. For example, employees dismissed as a result of more efficient management or production techniques are harmed by the formation of the cartel, but should not be viewed as suffering antitrust injury. To permit them to recover damages would deter the creation of productive efficiency and thus increase any welfare loss from the arrangement.

We see, then, that the traditional definition of damages for cartel practices is consistent with the idea of antitrust injury. It permits recovery for wealth transfers caused by the collusive restriction of output, but not for new wealth created by those aspects of the restraint that are efficient. As a logical extension, it should permit recovery for losses to purchasers who are unwilling or unable to meet the collusive price.

\section{B. Exclusionary Practices}

Allocative efficiency may also be impaired by predation. ${ }^{68}$ If,

66 Price fixing is, at any rate, a per se offense, one of those "practices which because of their pernicious effect on competition and lack of any redeeming virtue are conclusively presumed to be unreasonable and, therefore, illegal without elaborate inquiry as to the precise harm they have caused or the business excuse for their use." Northern Pac. Ry. v. United States, 356 U.S. 1, 5 (1958) (emphasis added). Price fixing is therefore illegal even if it increases efficiency by protecting investment in promotional activities, United States v. Sealy, Inc., 388 U.S. 350 (1967), or by making useful cost and production information available to producers. American Column \& Lumber Co. v. United States, 257 U.S. 337 (1921). The substantive law makes no exceptions, because economic techniques are viewed as inadequate to measure the welfare gains and losses from particular practices. See R. Bork, supra note 23, at 123. See also United States v. Topco Assocs., Inc., 405 U.S. 596, 609-11 (1972).

${ }^{67}$ See, e.g., FTC v. Procter \& Gamble Co., 386 U.S. 568 (1967); United States v. Philadelphia Nat'l Bank, 374 U.S. 321 (1963); Brown Shoe Co. v. United States, 370 U.S. 294 (1962). But see Williamson, supra note 65.

${ }^{68}$ The efficiency effects of predation are illustrated in the following diagram: 
for example, a would-be monopolist sets his price below cost (properly defined), customers may substitute away from less costly but competitively priced products of other firms. In addition, output at the lower price will expand to inefficient levels, because the cost of production exceeds the value consumers place on the product. The lower prices result in a wealth transfer (again, in itself neither efficient nor inefficient), this time from the producers to their customers. Furthermore, if successful, their predation will give the predator a greater market share, and, therefore, greater power to increase the price above cost, causing the additional welfare losses associated with monopoly.

It is important to recognize, however, that firms may engage in activities that necessarily involve exclusion of competitors but that are intended to increase productive efficiency. Thus, the mere fact that a firm has been excluded or foreclosed from selling does not necessarily mean that it has suffered antitrust injury. Similarly, by

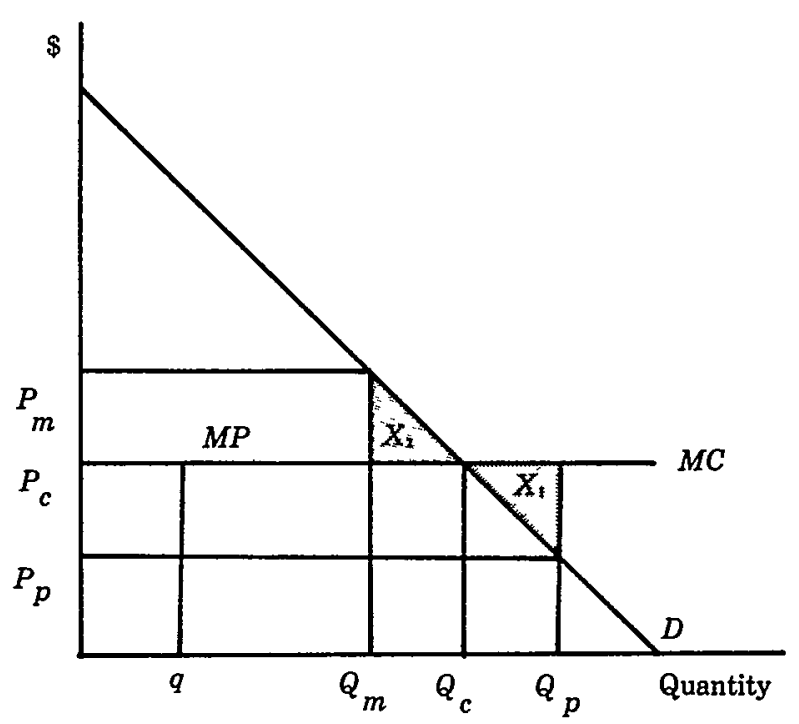

The object of the predator is to drive out of the market a competitor with output $q$, thereby permitting the predator to raise its price above marginal cost by setting $P_{m}$ at $Q_{m}$. To do this, it must increase industry output to drive the market price below cost. 'This results in inefficiently high output $Q_{p}$, since the cost of the marginal units of production exceeds the value given them by consumers. See Areeda \& Turner, Predatory Pricing and Related Practices Under Section 2 of the Sherman Act, 88 Harv. L. REv. 697, 712-13 (1975). The welfare loss during the period of predation is represented by the triangle $X_{2}$. If the predator is successful and is later able to restrict output to $Q_{m}$, there is an additional welfare loss $X_{2}$. See Janich Bros., Inc. v. American Distilling Co., 570 F.2d 848, 857-58 (9th Cir. 1977), cert. denied, 439 U.S. 829 (1978). 
the very act of competing by reducing prices or improving quality, firms deny each other some part of the market, thus reducing each others' profitability. Indeed, the more efficient a firm becomes in its production, the greater the "injury" it imposes on its competitors. ${ }^{69} \mathrm{It}$ is, therefore, important to distinguish legitimate competitive conduct from predation in defining antitrust injury, as the Court did in Brunswick. ${ }^{70}$ The principle we draw from Brunswick is that reductions in profit attributable to conduct by the defendant that preserves allocative efficiency or that increases its productive efficiency cannot be recovered as damages. ${ }^{71}$ A competitor should be compensated only to the extent he was harmed by the defendant's below-cost pricing. ${ }^{72}$

The traditional measures of damages for the total exclusion of a competitor from the market accurately reflect antitrust injury. Exclusionary practices usually fall into one of two patterns. In the first, a potential competitor is denied entry to a market because of the existing competitors' control of a necessary facility or resource. The inefficiency produced by such exclusion is clear; the expansion

69 See Janich Bros., Inc. v. American Distilling Co., 570 F.2d 848, 855 (9th Cir. 1977), cert. denied, 439 U.S. 829 (1978).

${ }^{70}$ By the same reasoning, a purchaser from a predator should recover only the increment in price attributable to the unlawful conduct, not the entire difference between the predator's price and a competitive price. See Berkey Photo, Inc., v. Eastman Kodak Co., 603 F.2d 263, 297-98 (2d Cir. 1979), cert. denied, 100 S. Ct. 1061 (1980); 3 P. AREedA \& D. TURNER, supra note 3 , at 73 .

71 The Court found that a judgment notwithstanding the verdict should have been entered for Brunswick, despite evidence assembled by the plaintiff that Brunswick had used its "deep pocket" to finance inefficient practices aimed at weakening independent bowling centers in the relevant markets. 429 U.S. at 489-90. The plaintiff's evidence of predation was, in the Court's view, unpersuasive. Id. at 490 n.15. By necessary implication, the Court's refusal to permit a retrial on the damage claim indicates that the Court viewed Brunswick's conduct as legitimately competitive.

The plaintiff's charges of deep-pocket predatory activity, both as to price-cutting and excessive promotional and capital expenditures, were part of a general contention that Brunswick operated its centers at a loss. Although the Court explicitly rejected the evidence of price cutting, it responded to the charge of below-cost operation by referring to the cash flow of Brunswick's centers in each market. By approving the continued operation of the centers with a positive cash flow, but an accounting loss, the Court accepted Brunswick's contention that " $[t]$ he crucial concern when one focuses on 'deep pocket' considerations should not be with paper 'profits' or 'losses,' but rather with whether cash flowed from petitioner to a bowling center or the other way." Brief for Petitioner at 10a-11a. In other words, the issue is whether the acquiring company is financing inefficient operation of the acquired company. If revenues exceed all economic costs, there can be no inefficiency.

72 See text at notes 98-105 infra. But see Purex Corp. v. Procter \& Gamble Co., 596 F.2d 881 (9th Cir. 1979). Purex stands Brunswick on its head by invoking it to permit damages in a merger case for lost profits flowing from increased compatition made possible by an unlawful merger. 
of industry output is impeded without any compensating gains in productive efficiency. To a degree, the injury to potential entrants mirrors the harm to consumers who do not purchase from cartelists at the cartel price: both are damaged by the allocative inefficiency created by the restricted supply. The courts have held that the excluded seller's damages should be based on the sales he would have made but for the boycott. Thus, in Zenith Radio Corp. $v$. Hazeltine Research, Inc., ${ }^{73}$ Zenith introduced evidence that it had been excluded from the Canadian market because of a Canadian patent pool's denial of the necessary licenses. Zenith's damages were determined by reference to its share in the United States market, which, the Court reasoned, Zenith could have duplicated in Canada but for the patent pool. The pool prevented Zenith from "securing a share of the market . . . which its business proficiency, demonstrated in the United States, dictated it should have obtained in Canada." "Such damages flowed from that aspect of the violation that caused inefficiency, since the damages reflected returns on output that the market would have supported but for the collusive impediment to new entry. ${ }^{75}$

In the second pattern of exclusionary practices, a group of firms exclude an actual competitor by some form of predatory conduct. The usual measure of antitrust damages for destruction of an existing business is its "going concern" value, which is the present value of the business's expected profits in the market over and above the ordinary rate of return on the firm's assets. ${ }^{76}$ Even after the exclusionary practice the firm still has its original assets, so the antitrust damages equal the loss of the special profit-making potential that those assets would have provided as part of a going concern. These damages are an appropriate measure of antitrust injury in the case of predation by competitors. They represent, in essence, the excluded firm's opportunity cost, which depends in part upon the price level in the market. Thus, the quantum of

73395 U.S. 100 (1969).

74 Id. at $124-25$.

${ }^{75}$ This measure would not be appropriate where the method of exclusion is a unilateral refusal to license patents, since exclusion is inherent in the grant of a patent monopoly. See SCM Corp. v. Xerox Corp., 463 F. Supp. 983, 1003-04 (D. Conn. 1978).

${ }^{78}$ See Standard Oil Co. v. Moore, 251 F.2d 188, 219-20 (9th Cir. 1957), cert. denied, 356 U.S. 975 (1958). See also Simpson v. Union Oil Co., 411 F.2d 897, 909-10 (9th Cir.), rev'd on other grounds, 396 U.S. 13 (1969) (per curiam); Vandervelde v. Put \& Call Brokers \& Dealers Ass'n, 344 F. Supp. 118 (S.D.N.Y. 1972). See generally Greenwald, Capitalized Pricing of Injury to Capital in Treble Damage Suits, 45 Connell L.Q. 84 (1959). 
damages is related to the size of the monopoly profits that the would-be predator expects to gain. Stated another way, the larger the output restriction by the successful predators, the greater the expected profits of the excluded firm had it remained in the market. Although these profits exceed an average rate of return, their loss is nonetheless antitrust injury, since they represent the potential return on output of a competitor excluded by the predators from the market.

\section{Mitigation of Damages}

The familiar principle that a plaintiff must mitigate his damages $^{77}$ is inherent in the idea of antitrust injury. The inefficiency created by a violation is the increase in cost that it causes. If the plaintiff does not follow the least costly alternative open to him, the added cost is attributable to the plaintiff's own actions, not to the violation. ${ }^{78}$ Thus, in Sun Cosmetic Shoppe, Inc. v. Elizabeth Arden Sales Corp., ${ }^{79}$ the court found that a retail cosmetic store that was discriminatorily denied "demonstrators" by its supplier could not recover consequential damages for any diversion of sales, since the plaintiff could have employed its own demonstrators. Damages were limited to the cost of finding and hiring the demonstrators. ${ }^{80}$ And more recently, in Golf City, Inc. v. Wilson Sporting Goods Co., ${ }^{81}$ a sporting goods retailer who was denied pro-line golf equipment was required to seek out substitutes and alternative sources of supply. In both cases, the courts recognized that to permit a plaintiff voluntarily to increase the costs associated with a violation and then to recover that amount as damages would be

77 See Golf City, Inc. v. Wilson Sporting Goods Co., 555 F.2d 426, 436 (5th Cir. 1977); Lehrman v. Gulf Oil Corp., 464 F.2d 26, $46-47$ (5th Cir.), cert. denied, 409 U.S. 1077 (1972); Lessig v. Tidewater Oil Co., 327 F.2d 459, 478 (9th Cir.) (Madden, J., dissenting), cert. denied, 377 U.S. 993 (1964); Sun Cosmetic Shoppe, Inc. v. Elizabeth Arden Sales Corp., 178 F.2d 150, 153 (2d Cir. 1949); William Goldman Theatres, Inc. v. Loew's, Inc., 69 F. Supp. 103, 104-05 (E.D. Pa. 1946), aff'd per curiam, 164 F.2d 1021 (3d Cir.), cert. denied, 334 U.S. 811 (1948); Lowry v. Tile, Mantel \& Grate Ass'n, 106 F. 38, 47 (N.D. Cal. 1900), aff'd sub nom. Montague \& Co. v. Lowry, 193 U.S. 38 (1904).

78 This distinction is inherent in the notion of economic or "opportunity" costs. See generally Coase, The Nature of Costs, in Studies in Cost ANaLYsis 118 (2d ed. D. Solomons 1968).

79178 F.2d 150 (2d Cir. 1949) (L. Hand, C.J.).

so Id. at 153. For a criticism of Sun Cosmetic, see State Wholesale Grocers v. Great Atl. \& Pac. Tea Co., 202 F.Supp. 768, 776-77 (N.D. Ill. 1961). See also K. ElzINGA \& W. BreIT, The Antitrust Penalties: A Study in Law and Economics 84-86 (1976).

${ }^{81} 555$ F.2d 426, 436 (5th Cir. 1977). 
anticompetitive. Damages are thus limited to the difference in value between the product or service that the injured plaintiff was denied and the closest available substitute. As Sun Cosmetic makes clear, however, if a violation causes the plaintiff to make such a substitution, the plaintiff should recover as damages whatever transaction costs he incurs, since these costs also represent resources wasted as a result of the violation..$^{\mathbf{8 2}}$

\section{The Public-Injury Doctrine}

At least one line of Supreme Court cases appears at first blush inconsistent with my. analysis of antitrust injury: the one limiting the requirement that the plaintiff allege injury to the public. ${ }^{83}$ The "public injury" doctrine, as enunciated by the lower courts, had in effect required that the plaintiff demonstrate with particularity how the defendant's conduct had restrained trade. ${ }^{84}$ The Supreme Court has held, however, that in cases of per se violations, an unreasonable restraint will be presumed, without any demonstration of harm to the public. In Radiant Burners, Inc. v. Peoples Gas, Light, \& Coke Co., ${ }^{85}$ for example, the Court said: "[t]o state a claim on which relief can be granted under [section 1], allegations adequate to show a violation and, in a private treble damage action, that plaintiff was damaged thereby are all the law requires."

Nothing in this line of cases is inconsistent with the requirement of antitrust injury. To say that the plaintiff need not show public injury in per se cases to establish the fact of a violation does not tell us what kind of individual injury should be compensable;

${ }^{82}$ But see Klein v. American Luggage Works, Inc., 206 F. Supp. 924, 945-48 (D. Del. 1962), rev'd on other grounds, 323 F.2d 787 (3d Cir. 1963).

${ }^{83}$ Continental Ore Co. v. Union Carbide \& Carbon Corp., 370 U.S. 690 (1962); In re McConnell, 370 U.S. 230 (1962); Poller Co. v. CBS, Inc., 368 U.S. 464 (1962); Radiant Burners, Inc. v. Peoples Gas Light \& Coke Co., 364 U.S. 656 (1961); Klor's, Inc. v. BroadwayHale Stores, Inc., 359 U.S. 207 (1959); Radovich v. National Football League, 352 U.S. 445 (1957).

84 See, e.g., Kinnear-Weed Corp. v. Humble Oil Ref. Co., 214 F.2d 891 (5th Cir. 1954); Fedderson Motors, Inc. v. Ward, 180 F.2d 519 (10th Cir. 1950).

ss 364 U.S. 656 (1961).

${ }^{88} I d$. at 660 . Subsequent cases in lower courts have held, however, that the plaintiff is still required to allege public injury-in the sense of conduct that unreasonably restrains trade-in cases that do not fall into the per se category. E.g., Kestenbaum v. Falstaff Brewing Corp., 514 F.2d 690, 699-700 (5th Cir. 1975), cert. denied, 424 U.S. 943 (1976); Lamb Enterprises, Inc. v. Toledo Blade Co., 461 F.2d 506, 517-18 (6th Cir.), cert. denied, 409 U.S. 1001 (1972); Arthur Murray, Inc. v. Reserve Plan, Inc., 406 F.2d 1138, 1145 (8th Cir. 1969); Juneau Square Corp. v. First Wis. Nat'l Bank, 435 F. Supp. 1307 (E.D. Wis. 1977). But see Syracuse Broadcasting Corp. v. Newhouse, 295 F.2d 269 (2d Cir. 1961). 
in a different context, that was the very point made by Brunswick. The inquiry into antitrust injury addresses the question of damages and does not even begin until the court finds that a violation has been alleged and that the plaintiff has been injured by it. The purpose of the inquiry is to determine whether and to what extent the plaintiff's injury flows from the kind of inefficiency to which the substantive law is directed.

\section{The Applications of ANTitrust InJURy}

We have seen that the concept of antitrust injury precludes recovery for injury caused by conduct that does not reduce allocative efficiency, but permits recovery of losses brought about by a curtailment of output through collusion or predatory conduct. What remains is to consider how the concept will change the law applicable to treble-damage actions. As this section will show, the concept can be used to refine some previously accepted measures of damages. The concept is also useful, however, in the treatment of issues now considered under the rubric of standing or affirmative defenses. By identifying the effects that an offense has on efficiency, a court may determine from the pleadings or after discovery whether the harm to the plaintiff could have flowed from the inefficiency.

\section{A. The Measure of Damages}

Much of the secondary literature dealing with proof of antitrust damages has been concerned with the degree of certainty and the kinds of evidence required to establish individual injury. ${ }^{87}$ The cases state the familiar proposition that a private plaintiff must prove the "fact" of his injury with a greater degree of certainty than its extent:

[T] necessary to establish the fact that petitioner had sustained some damage and the measure of proof necessary to enable the jury to fix the amount. The rule which precludes recovery of uncertain damages applies to such as are not the certain result of the wrong, not to those damages which are definitely attributable to the wrong and only uncertain in respect of

${ }^{87}$ E.g., E. Timberlake, Federal Treble Damage Antitrust Actions, (1968); Guilfoil, Damage Determination in Private Antitrust Suits, 42 Notre DAme LAw. 647 (1967). 
their amount. ${ }^{88}$

Antitrust injury, however, defines the kinds of damages that will be compensable by identifying the aspects of antitrust violations to which the plaintiff's injuries must be causally related. This qualificaton will necessarily affect the measure of damages in some cases, as the following examples show.

1. Maximum Price Fixing. The implications of Brunswick are most striking where a violation improves allocative efficiency directly. Consider, for example, the damage award reached by the lower courts after the Supreme Court's decision in Albrecht v. Herald $\mathrm{Co}^{89}$ Although of doubtful validity after Sylvania, ${ }^{90}$ Albrecht offers an illuminating example of the kinds of conflicts created by the damage remedy. The plaintiff was a carrier to whom the defendant newspaper had given an exclusive route subject to maximum resale prices. The plaintiff adhered to the price ceilings for a time, but later began charging a higher price. In response, the defendant, rather than terminate its agreement with the plaintiff, began to compete against him. Through a telephone solicitation service, the defendant drew away about one-quarter of the plaintiff's accounts in an attempt to make him comply with the maximum price, and appointed a temporary carrier to handle the accounts. When the plaintiff sued, the defendant notified him that he would be terminated, and allowed him sixty days in which to sell the route.

The plaintiff failed in the lower courts, but the Supreme Court reversed, finding an illegal combination among the defendant, the agency that solicited the plaintiff's accounts, and the temporary carrier. The Court reasoned that resale price fixing is illegal per se whether the price fixed is a maximum or minimum, although different arrangements may have different effects. ${ }^{91}$ Furthermore, the exclusive territorial arrangement, although assumed to be legal for the purposes of the litigation, did not justify the resale price fixing:

${ }^{88}$ Story Parchment Co. v. Paterson Parchment Paper Co., 282 U.S. 555, 562 (1931). Accord, Zenith Radio Corp. v. Hazeltine Research, Inc., 395 U.S. 100, 114 \& n.9 (1969).

${ }^{88} 390$ U.S. 145 (1968).

${ }^{\circ 0}$ Continental T.V., Inc. v. GTE Sylvania Inc., 433 U.S. 36 (1977). See Posner, The Rule of Reason and the Economic Approach: Reflections on the Sylvania Decision, $45 \mathrm{U}$. Chi. L. Rev. 1, 12 (1977).

${ }^{91}$ Minimum resale price maintenance may be an instrument of a dealers' cartel, or may benefit the manufacturer by increasing retail promotional activities or by reinforcing a cartel of manufacturers. 390 U.S. at $151 \mathrm{n}$.7. But maximum price fixing, according to the Court, "by substituting the perhaps erroneous judgment of a seller for the forces of a competitive market, may severely intrude upon the ability of buyers to compete and survive in that market." Id. at 152. 
"The assertion that illegal price fixing is justified because it blunts the pernicious consequences of another distribution practice is unpersuasive." 92

After a retrial on the issue of damages, the jury returned special verdicts on damages for three types of losses: profits lost as a result of the defendant's competition before the sale, the difference between the fair market value of the plaintiff's route at the time of the forced sale and the price actually received, and the plaintiff's future profits. ${ }^{93}$ The court of appeals affirmed the award as to the first two items of damage, but reversed the award of anticipated profits, because the value of the future profits was included in the fair market value of the business. ${ }^{24}$

The damage issue was litigated on the understanding that, after the Supreme Court's ruling on liability, the defendant could no longer "contest the fact that some damages would have to be awarded by the jury,"95 and that all damages causally related to the illegal conduct could be recovered. Brunswick suggests, however, that damages must be limited to the harm that flowed from the anticompetitive aspects of the defendant's conduct. Under the antitrust-injury approach, it was improper to award damages for profits lost because of the defendant's competition. The plaintiff was operating within an exclusive territory, with the consequent capacity to increase price above marginal cost by restricting output. ${ }^{98} \mathrm{By}$ its conduct, the defendant introduced new output into the market at a lower price, at the same time drawing accounts away from the plaintiff. There was no evidence that the defendant's prices were below cost or threatened the retailer's existence. Similarly, the award of damages for the reduced value of the business was also improper, since the size of the reduction was based upon capitalized profits attributable to the exclusive territorial arrangement. The plaintiff's loss of these profits is not the kind of harm the antitrust laws were intended to prevent.

This conundrum illustrates once again the conflict created by rigid rules of liability: although such rules may be necessary for

92 Id. at 154 .

's 321 F. Supp. 99 (E.D. Mo. 1970), aff'd in part and rev'd in part, 452 F.2d 124 (8th Cir. 1971).

94 452 F.2d 124, 131 (8th Cir. 1971).

93 Id. at 127.

o6 If the newspaper is itself a monopolist, it will set its output at $Q_{1}$ where its marginal revenue $(M R)$ equals its marginal cost $(M C)$, resulting in a price to the carrier of $P$. 
reasons of judicial economy and certainty, they may encompass clearly efficient conduct. The Court in Albrecht held that the existence of an exclusive territorial scheme did not justify an exception to the per se prohibition of price fixing. It did not deny, however, that conduct of the defendant designed to ensure adherence to the maximum resale price would be efficient in light of the "pernicious consequences" of the exclusive territories. The plaintiff should be denied recovery in these circumstances, not because he has received offsetting benefits from the illegal arrangement, ${ }^{97}$ but because his harm flows from an increase in output; the defendant's conduct has increased efficiency.

2. Predatory Pricing. There is a burgeoning academic literature on the subject of predatory pricing, most of it concerned with how properly to define the offense. ${ }^{98}$ Once a violation has been es-

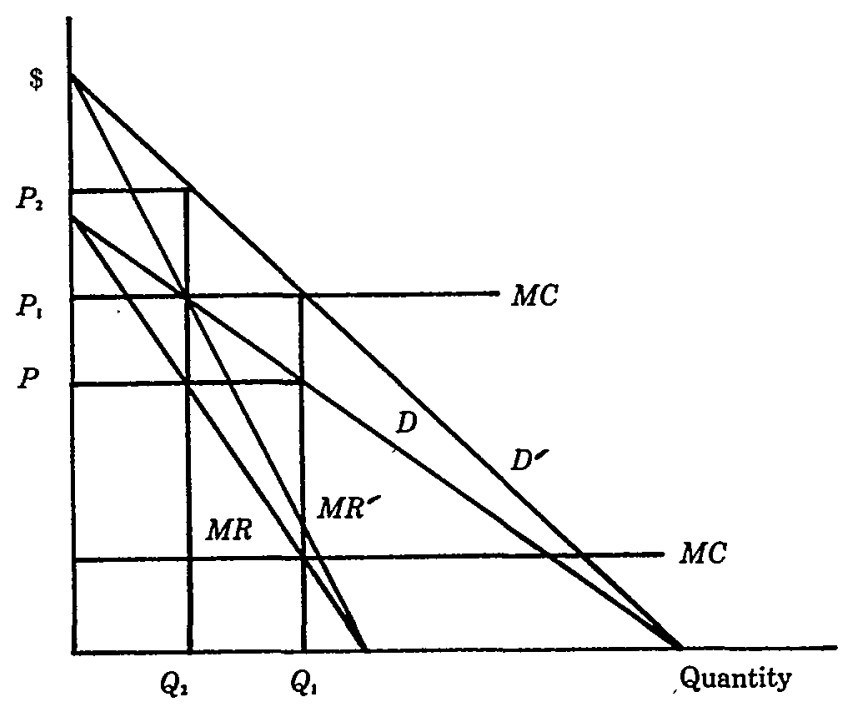

The market demand curve facing the carrier $\left(D^{\prime}\right)$ reflects the wholesale demand curve $(D)$ plus the cost of distribution. The carrier's marginal cost then is $P$ plus the cost of distribution, or $M C^{\prime}=P_{1}$. If the newspaper sets $P_{1}$ as its maximum (or if the retail level were competitive), the output would be $Q_{1}$ at $P_{1}$. But if the carrier, because of its exclusive territory, sets its own monopoly price, it will set $M C^{\prime}$ equal to its own marginal revenue $M R^{\prime}$, resulting in a lower output $Q_{2}$ and a higher price $P_{2}$.

${ }^{97}$ See 2 P. AREedA \& D. TuRner, supra note 3, II 347, at 255-56. A plaintiff should recover even if he has benefited from an illegal practice if the defendant's conduct reduces industry output.

${ }^{98}$ See, e.g., Areeda \& Turner, supra note 68. The recent literature and case law are surveyed in William Inglis \& Sons Baking Co. v. ITT Continental Baking Co., 461 F. Supp. 410 (N.D. Cal. 1978). 
tablished under one of the tests, however, the issue of which damages to treat as antitrust injury will remain. The principal inefficiency associated with successful predatory pricing is that it increases the predator's market share, allowing it to restrict output. As noted above, ${ }^{98}$ the usual measure of damages for the exclusion of an existing competitor from the market is the discounted value of its lost future profits as reflected in its going concern value. This measure, I argued, is properly treated as antitrust injury, since it represents return on the output that the defendant competitor has excluded from the market. There would seem to be no reason why the same measure of damages should not apply where predatory pricing results in the permanent exclusion of a competitor.

A different problem is raised, however, if the plaintiff was not excluded entirely, but incurred losses during the period of predation. As the Court said in Brunswick:

$\S 4$ plaintiffs [need not] prove an actual lessening of competition in order to recover. The short-term effect of certain anticompetitive behavior-predatory below-cost pricing, for example-may be to stimulate price competition. But competitors may be able to prove antitrust injury before they actually are driven from the market and the competition is thereby lessened. Of course, the case for relief will be strongest where competition has been diminished. ${ }^{100}$

What should be the measure of antitrust injury in these circumstances? During the period of predation there is a social cost imposed in maintaining output at levels higher than the product's value to society would justify. The costs to the predator in employing this tactic are extremely high: he must expand output and suffer losses on all units sold during the period of predation. The costs that the predator must bear are so high that some commentators doubt that a rational firm would ever use predatory pricing as a method of exclusion; ${ }^{101}$ at any rate, predatory pricing unquestionably imposes a substantial deterrent cost on the firm that tries to use it, even apart from any prospective damage liability. These costs must be considered when assessing damages, since the object of a damage award is to impose a cost on the predator sufficient to

\footnotetext{
92 See text at note 76 supra.

100429 U.S at 489 n.14 (citations omitted).

101 See, e.g., R. BoRK, supra note 23, at 149-55.
} 
deter any inefficiency. The danger of overdeterrence is particularly great in the imposition of penalties for reducing prices, a practice that is often competitive and that, in the short term, directly benefits consumers.

In Story Parchment Co. v. Paterson Parchment Paper Co., ${ }^{102}$ a case normally cited for its formulation of the degree of certainty with which damages must be proven, the Supreme Court implicitly recognized two measures of damages for injury caused by predatory pricing during the period of predation: the reduction in the victim's going concern value ${ }^{103}$ and the difference between the predatory price and the price that the victim would otherwise have received. ${ }^{104}$ The first of these measures would seem to be antitrust injury for the same reason that the loss in going concern value is the proper measure of damages for total exclusion: it represents a reduction in the profit-making potential of the firm and, as such, it corresponds to output restriction that the predator expects to make when he controls the market.

The Court's second measure of damage, however-the profit that the victim loses on sales during the period of predation-should not be compensable. ${ }^{105}$ This lost profit is simply a wealth transfer to consumers, which, as we have seen, is not in itself inefficient. Unlike the overcharges in price fixing, this wealth transfer does not directly benefit the defendant, and therefore is not the inducement to engage in predatory pricing. Of course, the lost profit is on sales made while industry output is inefficiently high. But it is the predator, not the victim, that must expand its production in order to maintain the market price below cost during the period of predation; the cost of producing the marginal units that increase industry output to inefficient levels is borne by the predator. Therefore the victim's lost profits during this period do not flow from the inefficiency. To allow them as damages, in addition to any reduction in going concern value, would be overdeterrence in an area where overdeterrence is particularly harmful.

3. Foreclosure. A more complex issue is presented by vertical associations such as mergers, tying arrangements, or exclusive dealing contracts that allegedly "foreclose" competing sellers from

102282 U.S. 555 (1931).

${ }^{103} \mathrm{Id}$. at $561-68$.

104 Id. at 561-66.

105 See Murphy Tugboat Co. v. Crowley, 454 F. Supp. 847, 853-57 (N.D. Cal. 1978). But see 2 P. AREedA \& D. Turner, supra note 3, I 344, at 231. 
all or part of the market. The Court in Brunswick indicated obliquely that different considerations would apply in foreclosure cases; "the case for relief will be strongest where competiton has been diminished," the Court noted, citing two damage cases involving foreclosure. ${ }^{106}$ As the Court implied, foreclosure is distinguishable from coercive exclusionary practices such as predatory pricing in that the former entirely eliminates rivalry in the supply of a product to a particular purchaser. But it is clear that such rivalry is not necessarily the same thing as overall competition. Since every contract or acquisition forecloses all but the contracting supplier from providing goods to the business affected, efficiency of distribution requires a degree of foreclosure, in the general sense. ${ }^{107}$

The courts have adopted in practice, if not in words, a presumption that foreclosure of a substantial percentage of the market by a merger, tying arrangement, or exclusive dealing contract, is illegal, regardless of the arrangement's actual competitive effects. ${ }^{108}$ The real object of this approach, however, should not be to prevent foreclosure in itself but the possible inefficient result of foreclosure, that is, an increase in monopoly power. Foreclosure may provide a judicial yardstick by which to administer the competitive standard consistently; foreclosure does not, however, reflect an actual reduction in competition in any meaningful sense. This distinction is important in the substantive law, and crucial to determining the appropriate measure of damages. The only accurate gauge of whether competition is reduced by foreclosure is the effect of the arrangement on industry output.

It therefore does not follow that every sale lost by a foreclosed rival because of the defendant's conduct represents antitrust injury. Yet that fallacy in the measure of damages was adopted by the court in Richfield Oil Corp. v. Karseal Corp. ${ }^{109}$ Karseal was foreclosed from selling its automobile wax through the defendant's service stations as a result of the defendant's requirement that its dealers carry only a competing brand of wax. In its claim for damages, Karseal noted that its wax sold three times better than the competing wax in the market as a whole. Thus, Karseal argued

108429 U.S. at 489 n.14 (citing Calnetics Corp. v. Volkswagen of America, Inc., 532 F.2d 674 (9th Cir. 1976); Metric Hosiery Co. v. Spartans Indus., Inc., 50 F.R.D. 50 (S.D.N.Y. 1970)).

${ }_{107}$ See Economic Perspective, supra note 23, at 196.

10s See note 68 supra.

102271 F.2d 709 (9th Cir. 1959), cert. denied, 361 U.S. 961 (1960). 
that if its product, instead of the competing brand, had been sold at the service stations, sales would have been three times greater. The court therefore awarded as damages Karseal's usual profit per case multiplied by these "lost sales." This measure did not, however, reflect antitrust injury, since it was unrelated to the effect of the restraint on output. The court assumed that the sales Karseal lost from the foreclosure were not or could not have been made by sales through other outlets. Since the foreclosed seller should be required to mitigate his damages, however, he should be required to seek alternative outlets; the mere fact that Karseal's product was not sold through one chain of outlets says little about the effect of the restraint on the product's sales in general. Yet Karseal offered no evidence that the consumers who supposedly would have purchased its product through the defendant's stations did not purchase it through other outlets in spite of the foreclosure.

Thus, at the very least, damages should be limited to the effect of the foreclosure on the defendant's overall sales. This was the principle adopted by the Court in 2361 State Corp. v. Sealy, Inc., ${ }^{110}$ in ruling on a motion for summary judgment. In that case, a bedding manufacturer was foreclosed from selling to one of its retail accounts by an exclusive dealing contract between a competitor and the account. But the manufacturer was allowed damages only to the extent that its business as a whole was injured, not for profit lost on sales to the contracting outlet viewed independently.

Although the overall-sales measure will preclude an award of damages in cases in which the foreclosure has no effect on the competitor's overall sales, it may overstate the injury when the defendant seller increases his output at the expense of its rival, but leaves industry output unaffected. In these circumstances, the reduction in the plaintiff's sales does not represent a reduction in industry output and should not form the basis of a damage recovery. The sales lost to the defendant would represent antitrust injury only if the vertical arrangement were used as a form of predation-that is, if it were accompanied by an increase in output through sales below cost. Foreclosure that reduced industry output or that was predatory would be deterred; but foreclosure with only an incipient effect on output, product quality, and so forth would

110263 F. Supp. 845 (N.D. Ill. 1967). See also Elder-Beerman Stores Corp. v. Federated Dep't Stores, Inc., 459 F.2d 138, 148 (6th Cir. 1972); Haden Co. v. Johns-Manville Sales Corp., 459 F. Supp. 1250, 1258 (N.D. Tex. 1978). 
be remedied by injunctive relief. ${ }^{111}$

\section{B. Antitrust Injury and Antitrust Standing}

We have seen that conduct that violates the antitrust laws may harm a single economic agent in a variety of ways, but that the concept of antitrust injury limits the plaintiff's recoverable damages to those flowing from the aspects of the violation that cause inefficiencies. By the same logic, only those plaintiffs who are harmed by the inefficiency-causing aspects of the conduct should recover. Determining who those plaintiffs are is normally treated as a question of standing, and the lower courts have, in fact, interpreted Brunswick as a standing case. ${ }^{112}$ But antitrust standing means more than the existence of antitrust injury to the plaintiff, ${ }^{113}$ and it is useful to keep the concepts separate. ${ }^{114}$

Antitrust injury is a rule of standing in the broad sense insofar as it defines the type of harm that is compensable; all of those plaintiffs who have not suffered this kind of harm necessarily lack standing to sue. The antitrust standing doctrine, however, narrows the class of those who may recover for antitrust injury. Within this scheme, antitrust injury defines that level of damages appropriate for carrying out the deterrent function. The rules of standing reinforce the deterrent function by preventing multiple recoveries or excessively complex or numerous lawsuits: the goal of deterrence would be just as certainly undermined by duplicative recoveries as it would be by recoveries for harms unrelated to the inefficiency caused by the violation. A damage award unrelated to the size of the injury increases the total social cost of antitrust enforcement. ${ }^{115}$

111 For an analysis of damages where foreclosure by a tying arrangement is the basis of a suit by a purchaser, see note 135 infra.

${ }_{112}$ See, e.g., John Lenore \& Co. v. Olympia Brewing Co., 550 F.2d 495, 498-99 (9th Cir. 1977); Juneau Square Corp. v. First Wis. Nat'l Bank, 445 F. Supp. 965, 969-70 (E.D. Wis. 1978).

113 See generally 2 P. AREedA \& D. TURNER, supra note 3, ीी 333-43; Berger \& Bernstein, An Analytical Framework for Antitrust Standing, 86 YALE L.J. 809 (1977); Sherman, Antitrust Standing: From Loeb to Malamud, 51 N.Y.U.L. Rev. 374 (1976); Lytle \& Purdue, Antitrust Target Area Under Section 4 of the Clayton Act, 25 AM. U.L. Rzv. 795 (1976); Note, Standing to Sue for Treble Damages Under Section 4 of the Clayton Act, 64 Colum. L. Rev. 570 (1964).

116 See Berger \& Bernstein, supra note 113, at 835-38; Handler, Changing Trends in Antitrust Doctrines: An Unprecedented Supreme Court Term-1977, 77 Colum. L. REv. 979, 996-97 (1977).

${ }^{115}$ See generally Dam, Class Actions: Efficiency, Compensation, Deterrence, and Con- 
Since we are concerned here with the proper scope of antitrust injury, we need not resolve how to determine in every case which plaintiffs should be denied standing because of the danger of multiple recovery or excessively complex litigation. As we shall see, however, correctly identifying the antitrust injury caused by a restraint would dispose of a range of cases now mistakenly viewed as ones of antitrust standing, and would simplify the legitimate questions of standing.

Courts have normally denied standing, for example, to employees dismissed as a result of their employers' antitrust violations. In Reibert v. Atlantic Richfield Co., ${ }^{116}$ an employee who was dismissed after a merger was denied damages because his injury was not proximately caused by the violation. Although the Court characterized the issue as one of standing, the language used by the Court suggests that the inquiry was closer to one of antitrust injury: the plaintiff's injury was "the natural effect flowing from two similarly structured businesses combining their assets to maximize efficiency," and "not a result of any lessening of commercial competition."117 In other words, the harm to the plaintiff resulted from an increase in productive efficiency rather than from an output restriction. ${ }^{118}$

The concept of antitrust injury also supports the court's result in Kirihara v. Bendix Corp. ${ }^{119}$ In that case, the plaintiff's exclusive distributorship was terminated, and another distributor was substituted, pursuant to a merger. The court denied relief on the ground that the plaintiff was not within the class of plaintiffs the statute was intended to protect and therefore lacked standing. But an antitrust-injury analysis leads to the same result: the substitution of one exclusive distributor for another can have no effect on industry output. The plaintiff's injuries stemmed solely from the suppliers' efforts to increase productive efficiency.

There are other cases in which a determination of antitrust injury would obviate the need for standing analysis. Thus, a plaintiff whose competitors are engaged in a price-fixing ${ }^{120}$ or market-

fict of Interest, 4 J. LEgal STud. 47 (1975).

${ }_{118}^{18} 471$ F.2d 727 (10th Cir.), cert. denied, 411 U.S. 938 (1973).

${ }_{117}$ Id. at 731 (quoting Conference of Studio Unions v. Loew's, Inc. 193 F.2d 51 (9th Cir. 1951), cert. denied, 342 U.S. 919 (1952)).

${ }_{11}$ See also Tugboat, Inc. v. Mobile Towing Co., 534 F.2d 1172, 1176 (5th Cir. 1976);

Mans v. Sunray DX Oil Co., 352 F. Supp. 1095 (N.D. Okla. 1971).

119306 F. Supp. 72 (D. Hawaii 1969).

${ }^{120}$ See Kemp Pontiac-Cadillac, Inc. v. Hartford Auto. Dealers' Ass'n, Inc., 380 F. Supp. 
allocation scheme ${ }^{121}$ should not recover damages, unless the scheme involves the setting of a predatory price or the exclusion of the plaintiff from the market. ${ }^{122}$ If price is raised above cost and the plaintiff is not prevented from reaching the market, he should not recover, since he may avoid any injury-or, indeed, benefit from the restraint-by setting a competitive price himself. Similarly, if a manufacturer adopts an exclusive territorial scheme to distribute his product, his competitors cannot suffer antitrust injury as a result. ${ }^{123}$ Such an arrangement, insulating the distributors from intrabrand competition, is intended to encourage the distributors to increase their promotional activities and thereby to increase demand for the manufacturer's product. If the arrangement is unsuccessful, the distributors will sell less; although competition would be reduced in that event, the competitors would not be damaged at all. If, however, the arrangement is successful and the distributors' additional services increase demand for the manufacturer's product, the competitors may suffer injury-but not antitrust injury. As in Brunswick, the competitors' losses are the result of an increase in competition.

Antitrust injury has a further implication in the standing context that is not so obvious. Plaintiffs may argue that the elimination of competition has harmed them by causing destructive externalities in production-by causing physical as opposed to pecuniary damages. Plaintiffs have argued, for example, that an agreement restricting the production of antipollution devices harmed them by increasing environmental damage. ${ }^{124}$ While it is plausible to suggest that a restriction in the output of preventive devices would cause an increase in whatever physical harm the devices were designed to avoid, these externalities should not lead to an award of antitrust damages. ${ }^{125}$ The concern of antitrust policy is with pecuniary harms brought about through distortions in the price mechanism; antitrust injury, likewise, should be limited to

1382 (D. Conn. 1974).

${ }^{221}$ See Bowen v. New York News, Inc., 522 F.2d 1242, 1255-56 (2d Cir. 1975), cert. denied, 425 U.S. 936 (1976).

${ }^{122}$ See generally Juneau Square Corp. v. First Wis. Nat'l Bank, 445 F. Supp. 965 (E.D. Wis. 1978).

${ }^{123}$ See Outboard Marine Corp. v. Pezetel, 461 F. Supp. 384, 401-02 (D. Del. 1978) (section 1 of the Sherman Act).

124 In re Multidistrict Vehicle Air Pollution, 481 F.2d 122 (9th Cir.), cert. denied, 414

U.S. 1045 (1973).

${ }^{225}$ See generally $\mathrm{R}$. BoRK, supra note 23, at 114-15. 
these kinds of harms. ${ }^{126}$ Furthermore, for practical reasons, it would be impossible to separate in an antitrust case which physical harms were caused by the reduction in competition, and which by other factors. These kinds of external diseconomies are more properly viewed as lying within the scope of environmental law or the law of torts.

Thus, a large number of cases typically treated as ones of antitrust standing can be disposed of by determining whether antitrust injury has been caused by the practice at issue. There remain cases, however, in which the injury to the plaintiff does flow from the anticompetitive aspect of the violation, but in which standing should be denied for other policy reasons.

One of the more ambitious scholarly attempts to develop a comprehensive approach to the standing issue argues that courts, in determining standing to sue, should balance a number of competing policies-those, for example, in favor of compensation and deterrence and those against "ruinous" or multiple recoveries. ${ }^{127}$ Our analysis suggests that the inquiry should be a good deal narrower. The concept of antitrust injury defines the kinds of harms that should be compensable in order to maintain the efficient level of deterrence. The function of antitrust standing should be complementary: to limit recovery to the plaintiff or class of plaintiffs who are in the best position to impose the deterrent penalty on the defendant. Under notions of standing, potentially duplicative recoveries should be barred and the full right of action given to the plaintiff in the best evidentiary position to recover. But standing should not be denied on the ground that an award of damages for antitrust injury would be "ruinous." If the award is not duplicative, then there is no justification for not imposing the full deterrent penalty. ${ }^{128}$

\section{Affirmative Defenses and Antitrust Injury}

In Perma Life Mufflers v. International Parts Co., ${ }^{128}$ the Supreme Court held that the equitable doctrine of in pari delicto is not an absolute bar to recovery in antitrust cases. Lower courts,

${ }^{128}$ Cf. NAACP v. New York Clearing House Ass'n, 431 F. Supp. 405, 411 (S.D.N.Y. 1977) (racial or sexual discrimination not antitrust injury).

${ }^{12 z}$ Berger \& Bernstein, supra note 113.

${ }^{128}$ But see Mid-West Paper Prods. Co. v. Continental Group, Inc., 596 F.2d 573, 587 (3d Cir. 1979).

129392 U.S. 134 (1968). 
however, have interpreted the various opinions in Perma Life to permit the denial of recovery where the parties to the suit are equally at fault. ${ }^{130} \mathrm{My}$ argument so far suggests that fault should not be the controlling criterion. The elimination of in pari delicto may be criticized for creating an incentive to engage in antitrust violations by assuring violators that if their plan turns out badly they can always sue their fellow wrongdoers for treble damages. But this, of course, ignores the other side of the coin: eliminating the absolute bar simultaneously deters the same persons by the threat that they, too, may be sued by their coconspirators. In some circumstances, a bar based upon in pari delicto could actually deter efficient conduct. Consider, for example, a dealer cartel that has induced a manufacturer to impose resale price maintenance. If one of the cartel members is terminated by the manufacturer for shading on price, he should be permitted to recover the going concern value of his business. ${ }^{131}$ Although by cutting price he has attempted to increase his share of the excess profit created by the cartel, ${ }^{132}$ his termination was nonetheless inefficient because it prevented an increase in industry output that would have weakened the cartel.

The concerns that underlie in pari delicto are, of course, legitimate, but they are often served equally well by permitting recovery only for antitrust injury. If a practice results in no present inefficiency, for example, then those injured by it should not recover, whether or not they participated in the scheme. In Dreibus v. Wilson, ${ }^{133}$ the officers of an exclusive distributorship succeeded in obtaining for themselves a new exclusive distributorship in the same product. The Court denied recovery in a suit by the owners of the first distributorship on the grounds that they were deeply involved in the illegal act. The same result follows, however, from an antitrust-injury analysis. ${ }^{134}$ The substitution of one exclusive distribu-

${ }^{130}$ See generally Note, In Pari Delicto and the Deterrence of Antitrust Violations, 62 Minn. L. Rev. 59 (1977); Note, A Re-Examination of In Pari Delicto Under the Antitrust Laws, 19 B.C.L. REv. 207 (1977).

${ }^{131}$ See Eastman Kodak Co. v. Southern Photo Materials Co., 295 F. 98, 102 (5th Cir. 1923), aff'd, 273 U.S. 359 (1927).

132 See Economic Perspective, supra note 23, at 12.

13s 529 F.2d 170 (9th Cir. 1975).

134 The court of appeals recognized this implicitly when it quoted with approval from the district court opinion: "The replacement of Velvet as a distributor could not worsen the competitive structure of the alleged market. A monopoly existed before the change; at worst, a monopoly existed afterwards." 529 F.2d at 174 (quoting unpublished district court opinion, at 5-7). 
torship for another created no new inefficiency. The plaintiff's injuries should not be compensable because they did not result from any inefficiency brought about by the defendants' actions, rather than because the plaintiffs were as much at fault as the defendants. ${ }^{\text {135 }}$

The plaintiff's own anticompetitive conduct should also in some cases determine whether the harm to it constitutes antitrust injury. This possibility is illustrated by Keifer-Stewart, Inc. v. Joseph E. Seagram \& Sons, Inc., ${ }^{136}$ a decision that (although technically concerned with the doctrine of "unclean hands" rather than in pari delicto) anticipated Perma Life in many respects. The plaintiff, a liquor wholesaler, claimed that the defendants collusively refused to deal with it unless it agreed to resell at a fixed maximum price. Although the defendants had offered evidence that the plaintiff was itself a member of a retail cartel, the Court found that the trial court had correctly instructed the jury that the plaintiff's conduct was not a defense. While the plaintiff's participation in a cartel did not estop it from challenging the defendant's antitrust violations, it was relevant to the issue of antitrust injury. If the retail price was collusively raised above the competitive level, then the defendant's maximum price increased output; to the extent the plaintiff should not recover the profits it lost as a result

195 Professor Areeda has argued on similar grounds that purchasers of products under illegal tie-in sales should normally not recover the full "overcharge" on the tied product as damages. Areeda, supra note 9, at 1136-38. See also 2 P. AREEDA \& D. TuRNER, supra note $3, \pi 347$. If the illegal tie is of products sold in fixed proportions, the purchaser is simply not injured: he would not have purchased the tied product at a supracompetitive price unless he was compensated by the seller with a reduction in the price of the tying product. Thus, Areeda argues (on the basis of certain language in Perma Life) that the seller should be allowed to set off the benefits that the purchaser derives from the contract in determining damages. If, on the other hand, the tie is declared illegal on the grounds of price discrimination-that is, if the tied product is sold in variable proportions according to the intensity with which the buyer uses the tying product-then there is still no injury to the purchaser. Although he may pay a higher price for the tied products, the seller could extract the same amount without the tie by directly metering the buyer's use of the tying product and charging a proportionate price for it. As Areeda points out, courts have recognized the propriety of varying the price of a product according to the intensity with which it is used; and if the same amount may be extracted by a less restrictive, and, therefore, legal means, then the damages are not actually caused by the illegal tie-in per se. Although phrased in terms of the "inherently offsetting" character of the injuries, both of Areeda's arguments are, at bottom, based on antitrust injury. In each case, since there is no restriction of production, the plaintiff incurs no damage that flows from inefficiency. The same reasoning could be applied to eliminate damages in the cases of exclusive dealing contracts and "noncoercive" reciprocity. For example, Columbia Nitrogen Corp. v. Royster, 451 F.2d 3 (4th Cir. 1971) is a case involving "noncoercive" reciprocity, to which the foregoing analysis could be applied.

${ }^{136} 340$ U.S. 211 (1951). 
of the defendant's refusal to deal. The fact that the plaintiff was denied cartel profits is no concern of the antitrust laws. ${ }^{\mathbf{1 3 7}}$

Thus, while in pari delicto should be discarded as a complete defense, its underlying rationale should be retained as a rule of damages. The goal of deterrence will be more completely achieved by limiting damages to antitrust injury than by the blunt instrument of a rule of estoppel based on fault.

\section{CONCLUSION}

The most trenchant recent criticism of substantive antitrust policy is that it reduces competition by restricting efficient business arrangements. ${ }^{138}$ But much of the expansion of antitrust liability over the last twenty years has resulted from a recognition that it is often difficult in an adversary system to prove what effects a given practice has on competition. The courts have therefore been willing to defer to the expertise of enforcement agencies, rather than to adopt a uniform rule of reason in antitrust cases.

The resulting rules, although not anticompetitive in their purpose, often are so in their practical effect, as the lower court's result in Albrecht demonstrates. Per se rules of liability can only be justified on grounds that they lighten the plaintiff's burden if the prospective plaintiff can be relied upon to weigh costs and benefits in its choice of cases. Since rigid rules necessarily cover a range of efficient conduct, the most significant cost to be considered in determining the optimal level of enforcement is the inefficiency the suit may produce. Although there are some random, even perverse, elements in the criteria for case selection by the Department of Justice and the Federal Trade Commission, ${ }^{139}$ those organizations have no clear incentive to bring anticompetitive cases, and seem to consider the efficiency consequences of their enforcement policies. ${ }^{140}$ The same cannot be said of private plaintiffs, who not only

${ }^{137}$ See Kestenbaum v. Falstaff Brewing Corp., 575 F.2d 564, 569-70 (5th Cir. 1978), cert. denied, 440 U.S. 909 (1979).

198 See R. BoRK, supra note 23, passim.

130 See Asch, The Determinants and Effects of Antitrust Activity, 18 J. LAw \& Econ. 575 (1975); Long, Schram \& Tollison, The Economic Determinants of Antitrust Activity, 16 J. Law \& Econ. 351 (1973); Posner, The Federal Trade Commission, 37 U. CH. L. Rev. 47 (1969); Posner, A Statistical Study of Antitrust Enforcement, 13 J. LAW \& EcoN. 965 (1970); Siegfried, The Determinants of Antitrust Activity, 18 J. LAw \& EcoN. 559 (1975). But see Masson \& Reynolds, Statistical Studies of Antitrust Enforcement: A Critique, in American Statistical Ass'n, 1977 Proceedings of the Business and Economic Statistics Secrion (Part I) 22.

${ }^{140}$ Address by Joel Davidow, "Policy Planning at the Antitrust Division," Intensified 
have the incentive to bring any case that holds out the prospect of treble damages, but frequently find it in their interest to prevent efficient conduct. If the damage provision's intended purpose of harnessing the self-interest of injured individuals to promote a policy of fostering efficiency is to be fulfilled, damages should be awarded in a way consistent with that policy. The concept of antitrust injury, whether viewed as a rule of standing or a measure of damages, helps serve this function by awarding damages only when the harm flows from the anticompetitive aspect of the violation. Since the aim of competition-and of antitrust policy-is to achieve an efficient allocation of resources, a plaintiff should not be permitted to recover for the injury from an antitrust violation that does not foster inefficiency. 